\title{
AKTYWNOŚĆ PRACOWNI ARCHEOLOGII ŚRÓDZIEMNOMORSKIEJ EPOKI BRĄZU W BADANIACH NAD STREFĄ EGEJSKA ZE SZCZEGÓLNYM UWZGLĘDNIENIEM ZAGADNIENIA BURSZTYNU W KULTURZE MYKEŃSKIEJ*
}

\author{
ACTIVITIES OF THE LABORATORY OF BRONZE AGE \\ MEDITERRANEAN ARCHAEOLOGY IN THE STUDY \\ OF THE AEGEAN AREA WITH SPECIAL EMPHASIS \\ ON THE ROLE OF AMBER IN THE MYCENAEAN CULTURE
}

\author{
Janusz Czebreszuk \\ Instytut Prahistorii, Uniwersytet im. Adama Mickiewicza \\ ul. Św. Marcin 78, 61-809 Poznań, Poland
}

\begin{abstract}
The Laboratory of Bronze Age Mediterranean Archaeology was established at the Institute of Prehistory in 2008. As a part of its framework a project of excavation in northern Greece has been conducted (Anthemountas Valley Archaeological Project - AVAP), to which two projects granted by the National Science Centre are related. Another research program of the Laboratory concerns the importance of amber in the Mycenaean culture. This has been the issue discussed in the article, and the main categories of archaeological data concerning the amber in Mycenaean world (typology, chronology, dispersion and routes it took to reach from the north) have been presented.
\end{abstract}

Powstała w Instytucie Prahistorii UAM w 2008 r. Pracownia Archeologii Śródziemnomorskiej Epoki Brązu swoje prace badawcze koncentruje z jednej strony na kwestiach powiązań tej strefy z pozostałymi (zwłaszcza usytuowanymi na północ od niej) regionami naszego kontynentu, z drugiej zaś na projektach dotyczących bezpośrednio obszarów egejskich w trakcie III i II tys. przed Ch. W tym przyczynku pochylę się na drugiej z wymienionych wyżej grupie zagadnień, a zwłaszcza na badaniach dotyczących obecności bursztynu w kulturze mykeńskiej.

${ }^{*}$ Przyczynek powstał w ramach projektu nr 2011.01/B/HS3/02175 finansowanego przez Narodowe Centrum Nauki. 
Pracownia oprócz badań nad znaczeniem sukcynitu od 2009 r. prowadzi projekt badań terenowych w dolinie rzeki Anthemous/Anthemountas (Anthemountas Valley Archaeological Project, w skrócie AVAP), która wpada do Morza Egejskiego, bezpośrednio na wschód od Salonik. Dolina ma ok. $350 \mathrm{~km}^{2}$ i jest geograficznie zlokalizowana w newralgicznym miejscu pomiędzy strefą Morza Egejskiego a Bałkanami. Był to ważny czynnik przy podejmowaniu decyzji o jej wyborze do pogłębionych badań. Projekt jest realizowany wspólnie z Uniwersytetem Arystotelesa (prof. Stelios Andreou) i 16 Eforatem dla Zabytków Prahistorycznych i Klasycznych w Salonikach (dr Maria Pappa). Dotyczy on interdyscyplinarnych badań przemian osadnictwa od rozwiniętej epoki neolitu do początków epoki żelaza, tzn. między $\mathrm{V}$ a początkami I tys. przed Chr. Badania obejmują prace powierzchniowe z rozszerzoną paletą metod nieinwazyjnych, w postaci zliczania materiału powierzchniowego oraz zbierania prób zabytków z powierzchni w ramach regularnej siatki (zbieranie całego materiału zalegającego na powierzchni jest nieproduktywne poznawczo z powodu jego ogromnej liczby). Nasze działania obejmują także prace pomiarowe stanowisk (tworzenie planów sytuacyjno-wysokościowych, zwłaszcza obiektów o własnej formie krajobrazowej w postaci tellów), prospekcje geomagnetyczne oraz odwierty i analizę naturalnych profili rejestrowanych w miejscach szczególnie intensywnych zniszczeń, których przyczyną jest zarówno przyroda (stoki okresowych cieków), jak i człowiek (rabunkowe wkopy na tellach). Na tym stosunkowo niedużym obszarze zarejestrowano 9 telli, kilka rozległych stanowisk neolitycznych oraz zbliżoną liczbę wyżynnych stanowisk z początku epoki żelaza (tzw. trapezu). Wszystkie one układają się w specyficzny i charakteryzujący się regularna rytmiką zmian system osadniczy. Projekt od 2011 r. zyskał wsparcie NCN w formie projektu badawczego. Ponadto od początku roku $2014 \mathrm{w}$ ramach AVAP realizowany jest jeszcze jeden projekt NCN, związany z przygotowaniem pracy doktorskiej przez mgr. Jakuba Niebieszczańskiego. Oba programy są w trakcie realizacji, dlatego też nie sposób jeszcze przedstawić daleko idących wniosków; to będzie możliwe na przełomie roku 2014/2015.

Jednym z głównych kierunków badań Pracowni Archeologii Śródziemnomorskiej Epoki Brązu naszego Instytutu jest problematyka bursztynu jako surowca ujawniającego kontakty kulturowe między mieszkańcami ówczesnej Europy Środkowej i strefy egejskiej ${ }^{1}$ oraz jego znaczenia w samej Grecji, zwłaszcza w ramach kultury mykeńskiej ${ }^{2}$. Temu ostatniemu poświęcony będzie głównie niniejszy przyczynek.

Zagadnienie dotyczące użytkowania bursztynu w kulturze mykeńskiej wiąże się z początkami archeologii egejskiej, a personalnie z samym jej założycielem - Heinrichem Schliemannem, który już w 1874 r., badając krąg grobów szybowych A

\footnotetext{
${ }^{1}$ Czebreszuk 2003; 2007; 2007a; 2009; 2009a.

${ }^{2}$ Czebreszuk 2011; 2012; 2013.
} 
w Mykenach odkrył pierwsze zabytki z tego surowca ${ }^{3}$. Były to przy tym od razu znaleziska najbardziej spektakularne, zarówno pod względem typologicznym, jak i ilościowym (ponad tysiąc artefaktów z grobu IV).

Dalsze lata badań przyniosły następne znaleziska, pochodzące także z Myken (krąg grobów szybowych $\mathrm{B}^{4}$ ) oraz $\mathrm{z}$ innych miejscowości, skoncentrowanych na Peloponezie. Wymienić należy zwłaszcza następujące obiekty: Dendra, grobowiec komorowy $10^{5}$, Kakavatos, tolos $\mathrm{A}^{6}$, Kaukaunara, tolos $2^{7}$, Nichoria, tolos „Veves”, Peristeria, tolos $2^{9}$, Pylos, tolos $\mathrm{IV}^{10}$ i Routsi, tolos $2^{11}$.

Po połowie XX w. pula informacji na temat obecności bursztynu w kulturze mykeńskiej była więc już znaczna. Problemem pozostawało jego pochodzenie, a podstawowe pytanie brzmiało: czy był to bursztyn bałtycki (sukcymit), czy też jakaś inna żywica kopalna, albo może także surowiec znany ze strefy egejskiej miał heterogeniczną genezę.

Rozwiązania tego problemu dokonał K.W. Beck, który wprowadził do analizy struktury fizykochemicznej bursztynu nową metodę, spektrometrii widmowej w podczerwieni ${ }^{12}$. Dzięki tej metodzie wykazał on, że bursztyn bałtycki ma specyficzny rodzaj widma, wyraźnie różniący się od innych żywic kopalnych. Stosując tę metodę, rozpoczął on program systematycznych badań poszczególnych zabytków bursztynowych pochodzących z wykopalisk w Grecji ${ }^{13}$. Wyniki tych badań wykazały ponad wszelką wątpliwość, że zdecydowana większość zabytków w najbardziej spektakularnych znaleziskach mykeńskich była pochodzenia bałtyckiego.

Na tak ukształtowanej bazie możliwy był do podjęcia problem mechanizmów kulturowych i dróg przekazu bursztynu bałtyckiego na południe, zwłaszcza do strefy egejskiej. Jest to kwestia znana w literaturze zwłaszcza pod hasłem badań nad szlakami bursztynowymi ${ }^{14}$. Obecnie w literaturze przedmiotu pojawia się kilka wersji szlaku bursztynowego w epoce brązu.

a. Skrajnie zachodnia droga morska, biegnąca na zachód do południowej Italii, na wybrzeża południowej Francji, Hiszpanii i wzdłuż wybrzeży atlantyckich Por-

\footnotetext{
${ }^{3}$ Schliemann 1878.

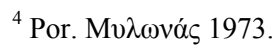

${ }^{5}$ Persson 1942.

${ }^{6}$ Müller 1909.

${ }^{7}$ Mapıvatos 1958.

${ }^{8}$ Harding, Hughes-Brock 1974.

${ }^{9}$ Mapivatos 1962.

${ }^{10}$ Blegen, Rawson, Taylour, Donovan 1973.

${ }^{11}$ Mapivatos 1957.

${ }^{12}$ Beck, Wilbur, Meret 1964; por. też Jaworski, Krauze, Lempka, Richter 1972.

${ }^{13}$ Beck 1966; 1970; 1996; Beck, Fellows, Adams 1970; Beck, Shustak 1982; Beck, Southard, Adams 1968; 1972.

${ }^{14}$ Por. klasyczna praca J.M. de Nawarro 1925.
} 
tugalii, Hiszpanii i Francji na Wyspy Brytyjskie. Mógłby to być szlak najbardziej związany z importem kornwalijskiej cyny. Bursztyn byłby tu czynnikiem ubocznym.

b. Zachodnia droga morsko-lądowa, która przebiega podobnie aż do ujścia Rodanu, gdzie zaczyna się jej odcinek lądowy, biegnący na północ do dorzecza Renu, a następnie przez kanał La Manche do Anglii lub wybrzeżem Morza Północnego do Jutlandii.

Obie te koncepcje wiązały się z mitycznym „szlakiem Herkulesa”"15, z którym cytowany autor wiążę przede wszystkim rozprzestrzenianie się w strefie egejskiej cynowych guzków z v-kształtnym otworem i miedzianych bereł sztyletowych ${ }^{16}$.

c. Centralna droga morsko-lądowa, która biegła wzdłuż wschodnich wybrzeży Adriatyku do regionu Caput Adria, gdzie zaczynał się jej odcinek lądowy. Co do przebiegu odcinka morskiego istnieje wśród badaczy pełna zgoda już od lat 20 . ubiegłego wieku. Równocześnie mówił o niej J.M. de Navarro ${ }^{17}$ i A. Evans ${ }^{18}$. Później ich pogląd powielany był w literaturze przez innych badaczy ${ }^{19}$. Nieco trudniejszą kwestią jest jego przebieg na odcinku lądowym oraz docelowy punkt na północy.

d. Stosunkowo najrzadziej pojawiającą się koncepcją jest szlak wyłącznie lądowy, biegnący w poprzek Bałkanów do Kotliny Karpackiej i bardziej na północ ${ }^{20}$. Podkreśla się $\mathrm{w}$ literaturze istotne utrudnienia, które mogły być z nim związane, chociażby łatwość zablokowania go w wielu ,punktach krytycznych”, jak liczne przełęcze czy przełomy rzek ${ }^{21}$.

e. Najbardziej wschodni szlak morsko-lądowy wyznaczany jest Morzem Egejskim do cieśniny Dardanele, a następnie zachodnim wybrzeżem Morza Czarnego do ujścia Dniestru i dalej w górę tej rzeki do dorzecza Wisły. Część lądowa rysowana jest jeszcze bardziej na wschód, z użyciem Dniepru i Dźwiny. Taki klasycznie wschodni zarys omawianego szlaku przedstawiała w swoich pracach M. Gimbutas ${ }^{22}$. Jego użyteczność jest uznawana zwłaszcza dla schyłkowych etapów epoki brązu ${ }^{23}$.

Zarysowane wyżej osiągnięcia stały się podstawą pierwszego podsumowania bursztyniarstwa mykeńskiego, co zostało wykonane przez Anthony'ego Hardinga i Helen Hughes-Brock w 1974 r. Podstawowym osiągnięciem ich pracy było sporządzenie pierwszego katalogu bursztynu w strefie egejskiej i terenach przyległych. Na lądzie stałym, Krecie i pozostałych wyspach obejmował on w sumie 61 miej-

\footnotetext{
${ }^{15}$ Evans 1928, 170.

${ }^{16}$ Evans 1928, 169-174.

${ }^{17}$ de Navarro 1925.

${ }^{18}$ Evans 1928, 174.

${ }^{19}$ Harding 1984; Czebreszuk 2009.

${ }^{20}$ Czebreszuk 2001.

${ }^{21}$ Bouzek 1985, 221.

${ }^{22}$ Gimbutas 1965, Fig.15; 1985.

${ }^{23}$ Ostatnio: Harding 2005, 299; Czebreszuk 2009a.
} 
scowości, na których zarejestrowano co najmniej 153 zespoły z bursztynem ${ }^{24}$. Cytowani badacze $\mathrm{w}$ sumie zarejestrowali w strefie egejskiej co najmniej 3411 zabytków z bursztynu ${ }^{25}$. Następne lata przyniosły dalszy wzrost ilości stanowisk z bursztynem, choć były to zazwyczaj znaleziska pojedyncze lub zawierające po kilka zabytków ${ }^{26}$.

Aktualne dane, po weryfikacji i kwerendzie bibliograficznej, są następujące. Bursztyn w kulturze mykeńskiej znany jest z 223 miejsc ${ }^{27}$. Zależnie od dokładności informacji są to pojedyncze pochówki w grobowcach zbiorowych, całe grobowce, cmentarzyska czy stanowiska. $Z$ tych miejsc znanych jest co najmniej 3523 zabytków, przy czym jest to suma znacznie zaniżona, zważywszy na ogólnikowość informacji o wielu odkryciach oraz brak publikacji końcowej prawie wszystkich stanowisk. Jest przy tym rzeczą charakterystyczną, że pod względem ilości miejsc ze znaleziskami bursztynu, najwięcej mamy ich w klasycznej fazie kultury mykeńskiej (1420-1200 przed Chr.), następnie we wczesnej (1700-1420 przed Chr.) i w końcu w późnej (1200-1060 przed Chr.). Z kolei inny jest obraz pod względem ilości zabytków bursztynowych znanych z każdej fazy. Tych najwięcej jest we wczesnej kulturze mykeńskiej, następnie w klasycznej i na końcu w późnej.

Zdecydowana większość miejsc pochodzenia bursztynu, niezależnie od fazy chronologicznej, to stanowiska sepulkralne. Związanych z nimi jest ok. 200 miejsc, w których zarejestrowano ten surowiec. Początkowo (okres wczesnomykeński) były to groby szybowe i tolosy oraz grobowce komorowe. W fazie klasycznej bursztyn nadal występował $\mathrm{w}$ tolosach, choć przeważały grobowce komorowe. Dla późnej kultury mykeńskiej pewne znaleziska lokalizowano tylko w tych ostatnich. Trzeba w tym miejscu podkreślić, że jedynie z grobów szybowych znamy realne ilości deponowanego bursztynu, gdyż w tolosach, jak i w grobowcach komorowych zachowały się tylko nieliczne ich resztki. Groby te były bowiem w większości wyrabowane już w czasach starożytnych.

Niewiele jest znalezisk osadowych i pochodzących z kontekstów wotywnych, przy czym te pierwsze to zapewne wyłącznie przedmioty zagubione ${ }^{28}$.

Pod względem typologicznym ${ }^{29}$ zdecydowanie przeważają paciorki, które znamy w kilkunastu odmianach. Najczęściej występują paciorki typu kulistego spłaszczonego, soczewkowatego, pierścieniowatego i kulistego. Rzadsze są formy elipsoidalne dwustożkowate, cylindryczne, beczułkowate i typu Tiryns. Natomiast w pojedynczych egzemplarzach znane są jeszcze inne typy, takie jak: Allumiere czy migdałowate. Inne rodzaje wytworów bursztynowych występujących w kulturze mykeńskiej

\footnotetext{
${ }^{24}$ Harding, Hughes-Brock 1974, Tab. 1.

${ }^{25}$ Harding, Hughes-Brock 1974, Tab. 1.

${ }^{26}$ Czebreszuk 2011.

${ }^{27}$ Czebreszuk 2011.

${ }^{28}$ Czebreszuk 2011, 136-151.

${ }^{29}$ Czebreszuk 2011, 75-97.
} 


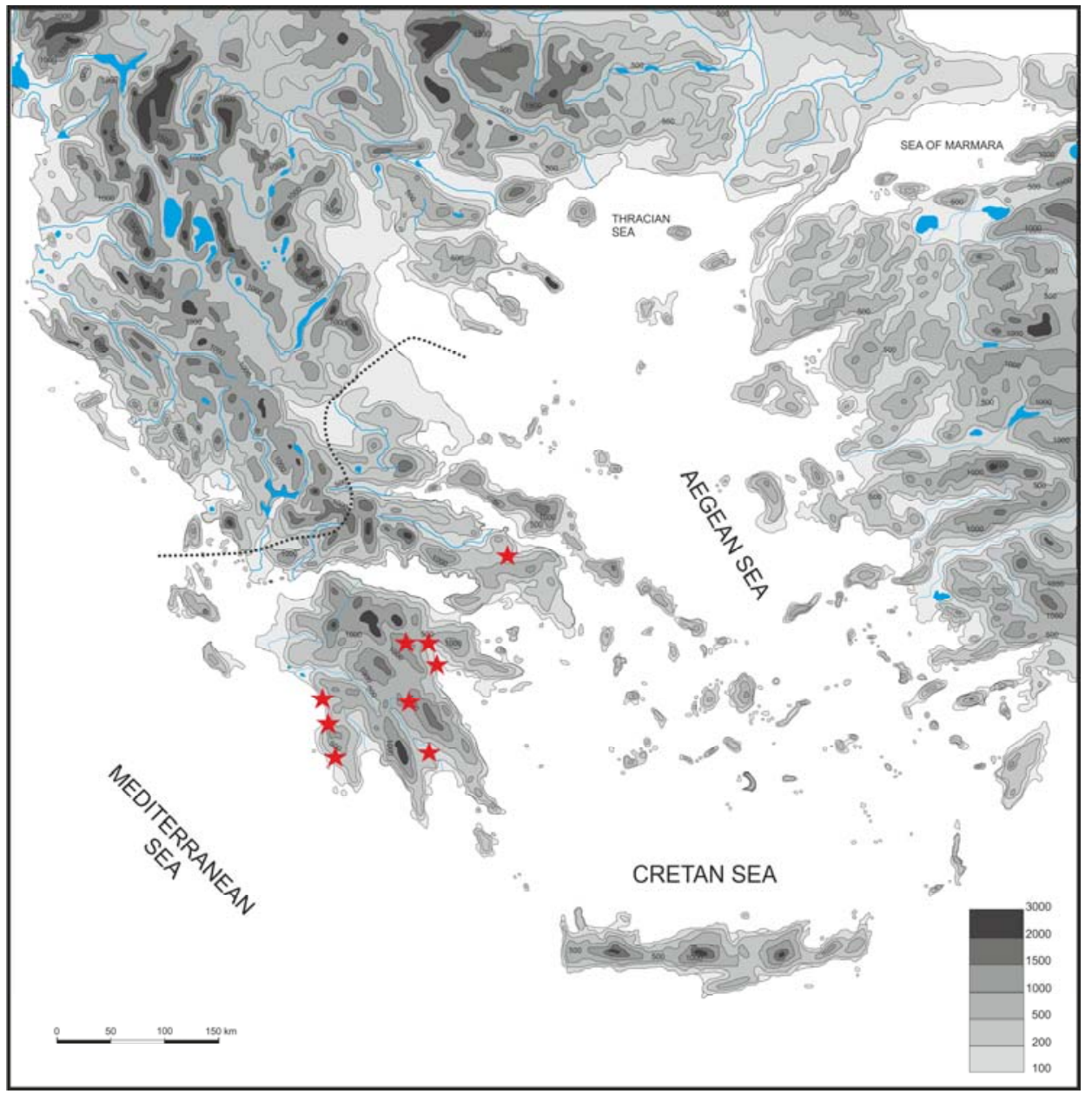

Ryc. 1. Dyspersja znalezisk bursztynowych w fazie wczesnej kultury mykeńskiej (naniesiono tylko znaleziska o jednoznacznej lokalizacji i chronologii). Linią przerywaną zaznaczono przybliżony zasięg kultury mykeńskiej (wg Czebreszuk 2011)

Fig. 1. Dispersion of amber finds in from the early phase of Mycenaean culture (only finds of undisputable location and chronology have been considered). Dotted line marking estimated extant of the Mycenaean culture (by Czebreszuk 2011)

to zawieszki, dyski i rozdzielniki - płaskie (najbardziej spektakularne, o prostym lub skomplikowanym układzie otworów) oraz o innych kształtach. Były one częścią składową pektorałów - skomplikowanych ozdób noszonych na piersi, złożonych $\mathrm{z}$ wielu korali paciorków bursztynowych stabilizowanych przez układ rozdzielników.

Część z wymienionych wyżej typów ma swoje znaczenie chronologiczne. Przykładowo rozdzielniki występują tylko we wczesnej kulturze mykeńskiej (między 
1700-1420 przed Chr.), natomiast paciorki typu Tiryns i Allumiere skupione są w późnej jej fazie (1200-1060 przed Chr.).

Pod względem geograficznym można mówić o stałym procesie rozprzestrzeniania się bursztynu w ramach ekumeny mykeńskiej. W fazie wczesnej znamy go wyłącznie z Peloponezu (plus jedno znalezisko z Teb w Beocji), zwłaszcza w Argolidzie i Mesenii (ryc. 1). W trakcie klasycznej fazy bursztyn występuje już w obrębie

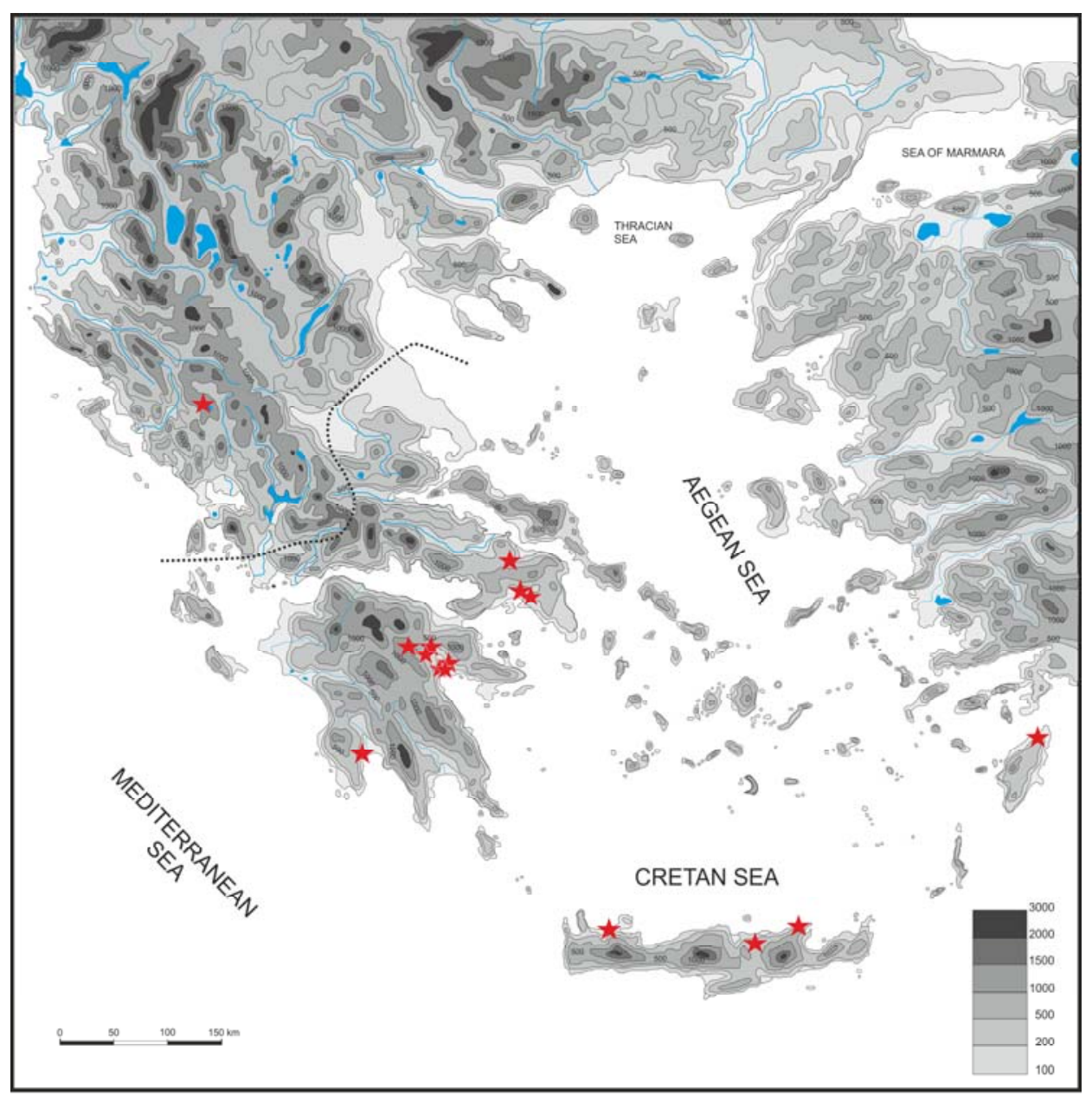

Ryc. 2. Dyspersja znalezisk bursztynowych w fazie klasycznej kultury mykeńskiej (naniesiono tylko znaleziska o jednoznacznej lokalizacji i chronologii). Linią przerywaną zaznaczono przybliżony zasięg kultury mykeńskiej (wg Czebreszuk 2011)

Fig. 2. Dispersion of amber finds from the classical phase of the Mycenaean culture (only finds of undisputable location and chronology have been considered). Dotted line marking estimated extant of the Mycenaean culture (by Czebreszuk 2011) 


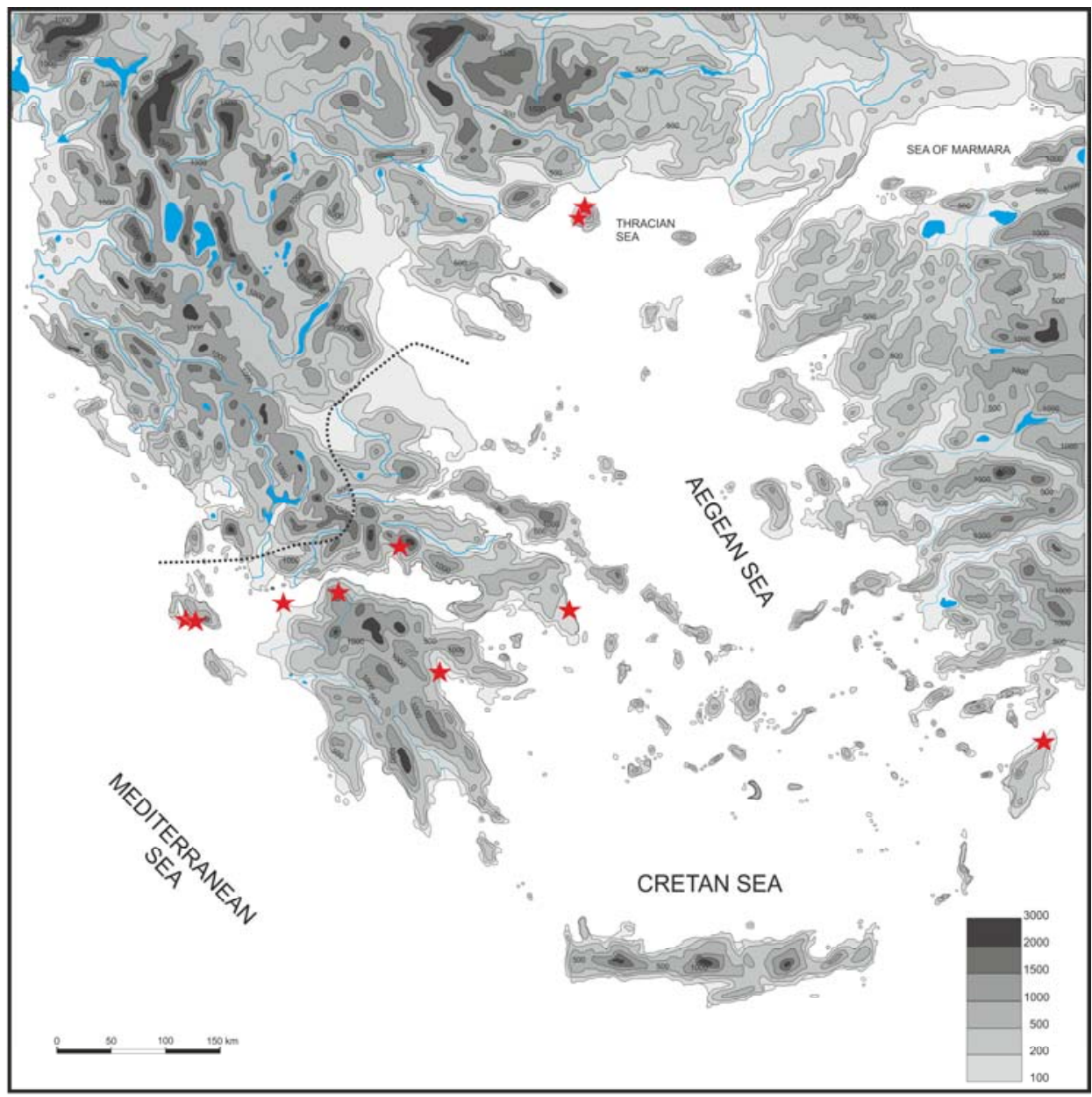

Ryc. 3. Dyspersja znalezisk bursztynowych w fazie późnej kultury mykeńskiej (naniesiono tylko znaleziska o jednoznacznej lokalizacji i chronologii). Linią przerywaną zaznaczono przybliżony zasięg kultury mykeńskiej (wg Czebreszuk 2011)

Fig.3. Dispersion of amber finds from the late phase of the Mycenaean culture (only finds of undisputable location and chronology have been considered). Dotted line marking estimated extant of the Mycenaean culture (by Czebreszuk 2011)

całej ekumeny kultury mykeńskiej, aż po południową Tesalię na północy i Kretę na południu (ryc. 2). Z kolei po $1200 \mathrm{r}$. przed Chr. wytwory z analizowanego surowca znane są też $\mathrm{z}$ regionów tworzących bezpośrednie obrzeża świata mykeńskiego, zwłaszcza na północy (ryc. 3).

Bursztyn miał niewątpliwie szczególne znaczenie religijne i prestiżowe dla społeczeństw kultury mykeńskiej (zwłaszcza we wczesnej fazie jej rozwoju), kiedy to 
jego występowanie ograniczone było wyłącznie do najbogatszych kontekstów w postaci grobów szybowych i tolosów, które uznawane są za miejsca chowania elit wczesnomykeńskich. Równie warty podkreślenia jest fakt, iż bursztyn w strefie śródziemnomorskiej jest specyficznie „mykeńskim” surowcem. Nie przemieszcza się swobodnie do innych centrów cywilizacji wschodniego śródziemnomorza, takich jak państwo Hetytów, Mezopotamia, Syria, Palestyna czy Egipt, z którymi mieszkańcy Egei utrzymywali stałe i ożywione kontakty kulturowe i handlowe. Pojawienie się w każdym z nich bursztynu jest każdorazowo skomunikowane $\mathrm{z}$ obecnością innych cech mykeńskich. Równie znamienne jest miejsce bursztynu w wewnątrzegejskich relacjach kulturowych, konkretnie: między światem minojskim i mykeńskim. Bursztyn na Krecie pojawia się wraz z opanowaniem wyspy przez Mykeńczyków.

Nie ulega więc wątpliwości, że relacja między bursztynem a kulturą mykeńską miała szczególny charakter i wchodziła w skład wyznaczników tworzących jej specyfikę w ramach sieci cywilizacyjnych centrów wschodniego śródziemnomorza. Badania nad głębszym poznaniem tej specyfiki trwają aktualnie w ramach projektów realizowanych w naszej Pracowni.

\section{BIBLIOGRAFIA}

Beck C.W.

1966 Analysis and Provenience of Minoan and Mycenaean Amber. I. Greek, Roman and Byzantine Studies 7, s. 191-211.

1970 Amber in Archaeology, Archaeology 23 (1), s. 7-11.

1996 Spectroscopic Identification of „Amber” and „Black Resin” from Asine [w:] Asine III. Supplementary Studies on the Swedish Excavations 1922-1930, red. R. Hägg, G.C. Norquist, B. Wells, Stockholm, s. 91-92.

Beck C.W., Fellows C.A., Adams A.B.

1970 Analysis and Provenience of Mycenaean Amber. III. Kakavatos, Greek, Roman and Byzantine Studies 11, s. 5-22.

Beck C.W., Shustak Ch.A.

1982 Provenance of Late Mycenaean Amber from Emporio, Chios, [w:] Excavations in Chios 1938-1955. Prehistoric Emporio and Ayio Gala, vol. II, S. Hood, Athens, s. 727-730.

Beck C.W., Southard C., Adams A.B.

1968 Analysis and Provenience of Mycenaean Amber. II. Tiryns, Greek, Roman and Byzantine Studies 9, s. 5-19.

1972 Analysis and Provenience of Mycenaean Amber. VI. Mycenae, Greek, Roman and Byzantine Studies 13, s. 359-385.

Beck C.W., Wilbur E., Meret S.

1964 Infrared spectra and the origin of amber, Nature 201, s. 256.

Blegen C.W., Rawson M., Taylour W., Donovan W.P.

1973 The Palace of Nestor at Pylos in Western Messenia, Vol. I, Princeton.

Bouzek J.

1985 The Aegean, Anatolia and Europe. Cultural Interrelations in the Second Millennium BC, Studies in Mediterranean Archeology, Göteborg, 29. 
Czebreszuk J

2001 Schyłek neolitu i początki epoki brąu w strefie południowo-zachodniobattyckiej (III i poczatki II tys. przed Chr.). Alternatywny model kultury, Poznań.

2003 Amber on the Threshold of a World Career, [w:] Amber in the Archaeology, red. C.W. Beck, I. Loze, J.M. Todd, Riga, s. 164-179.

2007 The role of the Sambian center in creating cultural meaning of amber in the third and second millennium BC. The outline of major problems, [w:] Long Distance Trade in the Bronze Age and Early Iron Age, red. J. Baron, I. Lasak, Wrocław, s. 179-193.

2007a Amber between the Baltic and the Aegean in the $3^{\text {rd }}$ and $2^{\text {nd }}$ Millennia BC (An Outline of Major Issues) [w:] Between the Aegean and Baltic Seas. Prehistory across Borders, red. I. Galanaki, H. Tomas, Y. Galanakis, R. Laffineur, Aegaeum, Universitè de Liège, vol. 27, s. $363-370$.

2009 The Northern Section of the First Amber Trail. An Outline of Significance for Civilization Development, [w:] Amber in Archaeology. Proceedings of the Fifth International Conference on Amber in Archaeology, Belgrad 2006, red. A. Palavestra, C.W. Beck, J.M. Todd, Belgrad, s. 100-109, 284-285.

2009a Ways of Amber in the Northern Pontic Area. An Outline of Issues, Baltic-Pontic Studies 14, s. 87-102.

2011 Bursztyn w kulturze mykeńskiej. Zarys problematyki badawczej, Poznań.

2012 Przyczynek do badań nad genezą bursztynu w kulturze mykeńskiej, Prace Muzeum Ziemi 50, s. 83-90.

2013 Mysterious Raw Material from the Far North. Amber in Mycenaean culture [w:] Counterpoint: Essays in Archaeology and Heritage Studies in Honour of Professor Kristian Kristiansen, red. S. Bergerbrant, S. Sabatini, BAR International Series, Oxford, s. 557-563.

Evans A.

1928 The Palace of Minos at Knossos, vol. II, London.

Gimbutas M.

1965 Bronze Age Cultures in Central and Eastern Europe, London.

1985 East Baltic Amber in the fourth and third Millennium BC, Journal of Baltic Studies 16 (3), s. 231-256.

Harding A.

1984 The Mycenaeans and Europe, London.

2005 Horse-Harness and the Origins of the Mycenaean Civilization, [w:] Autochthon: Papers Presented to O.T.P.K. Dickinson on the occasion of his retirement, red. A. Dakouri-Hild, S. Sherratt, BAR International Series 1432, Oxford, s. 196-300.

Harding A., Hughes-Brock H.

1974 Amber in Mycenaean world, Annual of the British School of Archaeology at Athens 69, s. 148-172.

Jaworski M., Krauze J., Lempka A., Richter S.

1972 Badania metodami chromatograficzną i spektrofotometryczną przedmiotów bursztynowych pochodzących z wykopalisk archeologicznych, Fontes Archeaologici Posnaniensies 21, s. $230-238$.

Müller K

1909 Alt-Pylos. II. Die Funde aus sen Kuppelgrabern von Kakavatos, Mitteilungen des Deutschen Archäologischen Instituts in Athens, Band 34, s. 269-328.

Navarro J.M. de

1925 Prehistoric Routes between Northern Europe and Italy Defined by the Amber Trade, The Geographical Journal 66 (6), s. 481-507. 
Persson A.W

1942 New Tombs at Dendra near Midea, Lund.

Schliemann H.

1878 Mycenae. A Narrative of Researches and Discoveries at Mycenae and Tiryns, London.

$\operatorname{M\alpha \rho v} \alpha \tau$ cos $\Sigma$.

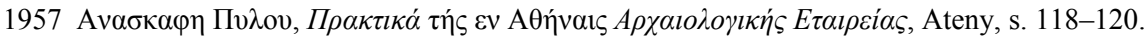

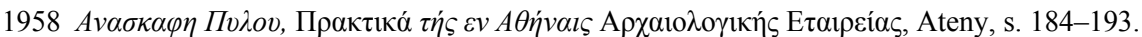

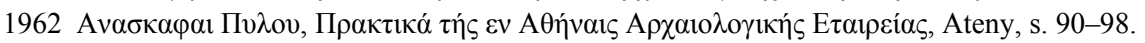

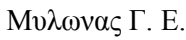

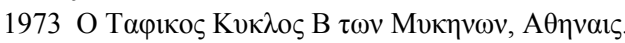

\author{
ACTIVITIES OF THE LABORATORY OF BRONZE AGE MEDITERRANEAN \\ ARCHAEOLOGY IN THE STUDY OF THE AEGEAN AREA WITH SPECIAL EMPHASIS \\ ON THE ROLE OF AMBER IN THE MYCENAEAN CULTURE
}

\title{
Su m m a r y
}

The Laboratory of Bronze Age Mediterranean Archaeology was established at the Institute of Prehistory in 2008. As a part of its framework a project of field works in northern Greece has been conducted (Anthemountas Valley Archaeological Project - AVAP), to which two projects granted by the National Science Centre are related. Another research program of the Laboratory concerns the importance of amber to the Mycenaean culture. This was the issue discussed in the article, and the main categories of archaeological data regarding the amber in the Mycenaean world were presented.

At the beginning, the major turning points in the history of research have been outlined, starting with Schliemann's excavations at Mycenae. Then, the quantitative, typological, chronological and spatial data concerning succinite in the Aegean world were summarized. Diversity of fossil resins (not just succinite) used in the Mycenaean world was also addressed. The important area of inquiry was to retrace a route or routes by which the Baltic amber reached from the north. Despite of the fact that some other fossil resins might have been available and located in regions closer to the Aegean area (like Sicily, Transylvania and Lebanon), it was succinite that played the most important role in the Mycenaean culture

As a result of observations, there is no doubt that the relationship between amber and the Mycenaean culture paid to its specificity within the network of centres of civilization of the Eastern Mediterranean. The research leading to a better recognition of this specificity have been ongoing within the projects carried out in our Laboratory. 
